\title{
The Chinese Junk Keying and American Racialization of Chinese
}

\section{Tao Zhang}

Sichuan International Studies University

\begin{abstract}
As the first Chinese wooden boat that ever reached the United States, the Keying, with its 40 Chinese sailors who composed the hitherto largest group of Chinese in America, not only satisfied Americans' curiosity at Chinese junks and Chinese people, but prompted a nationwide attempt at racializing Chinese from 1847 to 1848. This prototypical Chinese racialization features a configuration in which Chinese were triangulated vis-a-vis American whites and nonwhites. Whites occupied the upper corner of the triangle, commanding discursive tools of mass publications to position Chinese relative to whites themselves and other minority groups on America's racial ladder. Chinese were defined as an inferior, pitiable racial other that resembled Indians in appearance and stood somewhere in between Mexicans and blacks in terms of racial advancement. The triangular paradigm continued to function in American racialization of Chinese even after the departure of the Keying for Britain in February 1848, though with noticeable modifications.
\end{abstract}

Keywords: Chinese junk, America, racialization, triangulation

Measuring 150 feet long and 25 feet broad, the Keying was built of teak wood. A British merchant purchased it at Canton and intended to sail straight to London. But inclement weather and low provisions compelled its captain, Charles Kellet, to go to the United States instead. ${ }^{1}$ After reaching New York in mid-July 1847, the junk docked at different northeastern American ports and exhibited Chinese curiosities until February 17, 1848,

1 A Description of the Chinese Junk, "Keying," $4^{\text {th }}$ ed. (London: Printed for the Proprietors of the Junk, and Sold Only on Board, 1848), 5-7, 9. 
when it resumed its interrupted journey to Britain. In addition to a significant collection of Chinese artifacts, roughly forty Chinese sailors resided on the ship during its voyage to and in America. Kellet also exhibited the Keying in London and other British ports for a few months before it was sold and dismantled in Liverpool. ${ }^{2}$

The experience of the vessel in the U.S. interests many scholars, who depict the junk as a participant in U.S. exhibition and performance culture and a window to China for ordinary Americans. Arthur Bonner is one example. Contextualizing the Keying in the mid-nineteenth century American fashion of visiting curiosities, he holds that the junk satisfied American audiences' desire for the bizarre. A book that studies the river history of Providence, Rhode Island, mentions the festive atmosphere created by the junk, which, together with other vessels coming from afar, brought local people "a different culture."

Other scholars consider the Keying to be part of a larger strain of American orientalism that focused on the exoticness and inferiority of China and its people. In John Rogers Haddad's interpretation, the Chinese junk had metaphorically sailed into the whirlpool of America's worsening image of China. He contends that the British captain conspired with the New York Herald to craft a negative image of China consistent with American stereotypes. ${ }^{4}$ Terming the junk in press depictions a "packaged" other, John Kuo Wei Tchen agrees to Haddad's basic position. However, he believes that the American Magazine, which expressed Christian benevolence to Chinese sailors, actually joined the New York Herald in constructing "the commercially driven form of orientalism" surrounding the Keying. A similar view governs Krystyn R. Moon's treatment of the junk. To Moon, Chinese sailors' songs, dances, and music not only failed to improve American perceptions of China, but more seriously, occasioned the deterioration of existing ones. ${ }^{6}$ Sean Metzger discovers that the Keying served as a substitute

2 “Chinese Junk 'Keying," American Marine Engineer, Dec. 1915, 11.

3 Arthur Bonner, Alas! What Brought Thee Hither? The Chinese in New York 1800-1950 (Madison, NJ: Fairleigh Dickinson University Press, 1996), 2; Robert A. Geake, A History of the Providence River with the Moshassuck, Woonasquatucket \& Seekonk Tributaries (Charleston, SC: History Press, 2013), 124.

4 John Rogers Haddad, The Romance of China: Excursions to China in U.S. Culture, 1776-1876 (New York: Columbia University Press, 2008), 129-51.

5 John Kuo Wei Tchen, New York before Chinatown: Orientalism and the Shaping of American Culture 1776-1882 (Baltimore: Johns Hopkins University Press, 1999), 63-71.

6 Krystyn R. Moon, Yellowface: Creating the Chinese in American Popular Music and Performance, 1850 s- 
for "the circus-like exhibitions of people," convinced that contemporary Americans must have spent a leisurely time seeing those exotic Chinese.?

Stephen Davis has published the only book-length monograph on the Keying up to now. But the stay of the junk in the United States accounts for merely one and a half chapters out of a total of twelve whereas the bulk of the book discusses the boat's experiences on the seas and in Great Britain. When Davis focuses on the Keying in America, he seems most interested in proving that the English captain Kellet was actually not the rogue depicted by a New York court in the lawsuit over wages overdue to his Chinese crew. To substantiate this point, Davis cites American prejudice against the British, possible cultural misunderstandings between Kellet and his sailors, Kellet's ignorance of the content of his contract with the Chinese, and the change of Western maritime law as likely causes for the captain's bad name. ${ }^{8}$

Based mainly on secondary or even implied evidence, Davis's stance is simply not justifiable in view of the primary sources that I have found and will cite in this essay. Since my goal is to analyze American racialization of the Keying Chinese, I will not specifically comment on his idea in the following paragraphs. Those other aforementioned arguments are admittedly sound, but they just stop at revealing Americans' racist views of Chinese, failing to come up with a paradigm that could explain how Americans racialized Chinese before massive Chinese immigration in 1849.

The famous white-black binary used to dominate interpretations of racialization subjects. But since the last decade of the twentieth century, calls for more nuanced treatments have been more audible. In Margins and Mainstreams: Asians in American History and Culture, Gary Okihiro argues that "yellow is neither black nor white" and that Asian Americans have been a group sui generis receiving "special opportunities" and facing "unique disabilities." Analyzing the racial composition in nineteenth-century California, Tomas Almaguer comes to an identical conclusion. He alleges that the white-black binary perspective "offers little understanding of what hap-

1920s (New Brunswick, NJ: Rutgers University Press, 2005), 59, 62.

7 Sean Metzger, Chinese Looks: Fashion, Performance, Race (Bloomington, IN: Indiana University Press, 2014), 37.

8 Stephen Davis, East Sails West: The Voyage of the Keying, 1846-1855 (Hong Kong: Hong Kong University Press, 2014), 119-53.

9 Gary Y. Okihiro, Margins and Mainstreams: Asians in American History and Culture (1994; Seattle: University of Washington Press, 2014), xi-xii. 
pens when more than two racialized groups are competing," believing that "each ethnic group was racialized in unique ways." ${ }^{10}$ Other scholars have followed the lead and challenged the white-black dichotomy in their own ways. For example, Angelo N. Ancheta believes that the model fails "to recognize that basic nature of discrimination can differ among racial and ethnic groups." Calling Latinos and Asians the racial middle of America, Eileen O'Brien holds that the characteristics of neither group can be completely reduced to "the patterns typical of whites or blacks." They therefore have their own special experiences of getting racialized into American society. ${ }^{11}$ Claire Jean Kim not only echoes "the call to go 'beyond Black and White,"' but proposes a brand-new approach to Asian Americans' racialization: Asian Americans, including Chinese, have been "racially triangulated vis-a-vis Blacks and Whites," whereby whites "valorize" Asians' cultural and racial features relative to blacks but "ostracize" them from political and civic rights in an effort to effectively dominate both Asians and blacks. ${ }^{12}$

The current article seeks to continue the tendency. While treating the boat-caused comments as American whites' earliest attempt at racializing Chinese as a group outside the black-white binary, I wish to borrow Kim's concept of triangulation. Yet the triangle I will draw is a bit different. Chinese were indeed triangulated, but with whites and several non-white groups. On one edge, American whites placed Chinese under both voyeuristic gazes and paternalistic care, treating them as a backward and pitiable other. Valorization of Chinese cultural or racial features was scarce, if not non-existent. Another edge denotes whites' intention to liken Chinese to similarly racialized groups, which include not merely blacks, but also Mexicans and Indians. On the bottom edge could be seen the result of white comparison of Chinese to these three groups. Chinese emerged from this triangulated racialization as a bizarre and immature group that resembled Indians in appearance and stood between Mexicans and African Americans on the social hierarchy.

To explicate this pattern, the essay draws upon American historical news-

10 Tomas Almaguer, Racial Fault Lines: The Historical Origins of White Supremacy in California ( Berkeley, CA: University of California Press, 1994), 2, 6.

11 Angelo N. Ancheta, Race, Rights, and the Asian American Experience, $2^{\text {nd }}$ ed. (New Brunswick, NJ: Rutgers University Press, 2006), 13; Eileen O'Brien, The Racial Middle: Latinos and Asian Americans Living Beyond the Racial Divide (New York: New York University Press, 2008), 2.

12 Claire Jean Kim, “The Racial Triangulation of Asian Americans,” Politics \& Society, 27 (Mar. 1999), 105, 107. 
papers (searchable through Readex and the Library of Congress databases) and related archives of other kinds, including court records and promotional pamphlets. These sources were obviously produced by whites. A search in the Readex African American Newspapers, Ethnic American Newspapers, and Hispanic Newspapers databases turned out no result, which means that nonwhite press was disinterested in the Keying. Neither did I find any other types of ethnic American documents on the junk. But there exists a Chinese-language memoir written by a Chinese merchant who happened to be in New York when the vessel stayed in that city. He recorded graphically how he learned of the sailors' sufferings and eventually helped them win a lawsuit. Not cited by scholars before, this piece is a useful supplement to American newspapers and archives. I will dig up the information that illustrates the tripartite mechanism and ignore those descriptions which only advertised the exhibition of the vessel. Admittedly these sources may not be able to reflect Americans' attitude to China and Chinese in its entirety, but they are definitely telling of how articulate white Americans approached and racialized Chinese in the middle of the nineteenth century.

\section{Voyeuristic Gazes}

Americans had indeed seen or heard of individual Chinese visiting and leaving the United States before, but the Keying provided them with the first chance to observe a Chinese vessel and a large group of Chinese at close distances. They naturally grasped this opportunity. What they found or proclaimed to have found was retarded Chinese development and lowly Chinese taste, both cultural and gastronomical. Praises were also voiced, but only rarely.

"Odd" and "strange" were the words that Americans most often used when describing the junk. The oddity or strangeness of the Keying in turn suggested Chinese backwardness in ingenuity and practical techniques, which pointed to the inferiority of the Chinese who made and used it. On July 22, 1847, the Morning News of New London, Connecticut sounded most sarcastic by likening the boat to "a junk of jerked beef," considering its symmetry no more desirable than "the 'old junk' sold in the scrap shops in New-York." The editor vowed that even a butcher's gambril would outsail the Keying in smooth water and the Chinese vessel could only beat a 
bread tray in a race "with a fair wind and plenty of it."13 On September 13, a Buffalo, New York, resident declared his "disappointment and chagrin" at "the great Chinese Junk of nonsense." Not only did he belittle Chinese boat-building techniques manifested on the Keying, he also related the alleged technical backwardness to Chinese mental retardation. He warned Americans against expecting anything more advanced from China than the junk, which was deemed the highest achievement that Chinese heathens, "self-conceited, untractable," could make. He firmly believed that if "a common Yankee" had all the tools and equipment, he could easily "make a better craft" or he deserved "expatriation without benefit of clergy." 14

From the clumsy and outdated looks and apparel of the junk, other Americans deduced the stasis of Chinese civilization. The New York Herald called the Keying "the exact model of the vessels which that people [Chinese] constructed two thousand years ago," asserting that Chinese "are particularly attached to old notions and will not permit the slightest innovation in any thing." 15 On November 24, 1847, after the junk arrived in Boston, the editor of the Boston Daily Bee professed having seeing it in New York and felt entitled to assuring strangers that the Keying was a "Noah's Ark, on a modified plan." He urged people to spend the Thanksgiving holiday visiting "this queer craft." ${ }^{16}$ Of course, these exaggerations were aimed at hiking the number of visitors, but all the same, they helped spread among Americans the message of a static Chinese civilization.

Many Americans were not satisfied with merely looking around the junk itself, but took the opportunity to study the Chinese as exotic others. The results overwhelmingly bespoke Chinese inferiority, implying their suitability to be objects of American condescending gazes.

To some people the sailors appeared child-like. On July 15, 1847, the Pennsylvania Freeman called the sailors "yellow rascals" as if they were naughty kids. Besides, it noticed that while American passengers on a nearby ship laughed at the "unwieldy hull" of the Keying and "the comical popping up of Chinamen's heads along the bulwarks," the Chinese did not react as mature adults should, but enjoyed "the fun quite as well as any of the spectators...to the great delight of all their audience." ${ }^{17}$ Another depiction

13 “Capt. Bacon," Morning News, Jul. 22, 1847, 2.

14 "Correspondence of the Constitution," Constitution, Sept. 29, 1847, 3.

15 "The Chinese Junk," New York Herald, Jul. 27, 1847, 2.

16 "The Chinese Junk," Boston Daily Bee, Nov. 24, 1847, 2.

17 “The Chinese Junk," Pennsylvania Freeman, Jul. 15, 1847, 3. 
told of "a pleasant fellow" from the junk, who, like a small child, managed to accomplish "the feat of counting ten upon his fingers." Having done something so primitive intellectually, the sailor was "delighted beyond the power of expression--in any language we could understand." 18

Even the so-called mandarin aboard, Hesing, did not escape similar descriptions. The British captain advertised him as a Chinese official "of the fifth class," but no reliable sources could confirm this identity. ${ }^{19}$ During the stay of the Keying in New York, the local Farmers' Club organized two excursions to Long Island to choose a proper site for an agricultural college in the offing. Hesing and another Chinese from the junk attended one of the train trips "with great propriety." According to an account, when the train sped into a tunnel, the Chinese exhibited "every symptom of alarm," even their queues standing up in "a complete perpendicular with fright." They thought they were taking "a short cut through the bowels of the earth" back to Canton and "nothing could exceed their delight" at seeing daylight again. The Chinese then found the railroad contrivance "a complete riddle" despite their hard efforts to understand. Hesing even "laughed outright at the idea of feeding the iron horses on blocks of wood. ${ }^{20}$ In the New York Herald, Keesing [Hesing] and his companion Chin-chin were so excited about the eye-opening trip that "a continual chattering was heard the whole night" after their return to the boat. Keesing was said to be "exceedingly pleased" at the locomotive whistle and had been trying to imitate the "shrill sound." The paper advertised this action by the Chinese as a curiosity that was "worth twice the price of admission." 1

Joining those voyeuristic observers of the Chinese was the then wellknown phrenologist Orson Squire Fowler (1809-87). In his article published in American Phrenological Journal and reprinted in the Connecticut Republican Farmer, Fowler "carefully" examined the head of the Chinese painter on board, finding it "considerably under size," though he admitted seeing signs of firmness, adhesiveness, parental love, and other admirable virtues. Fowler went on to point out that those Chinese generally evinced "a state of civilization, quite inferior to our own, and an approach nearer

18 “Astonished at Last,” New-York Commercial Advertiser, Jul. 22, 1847, 2.

19 A Description of the Chinese Junk, 10.

20 "Country Excursions of the Farmers' Club," Dwight's American Magazine, and Family Newspapers, Oct. 2, 1847, 631; “Chinamen on a Railroad," Southern Patriot, Aug. 12, 1847, 2.

21 "Chinese Junk," New York Herald, Aug. 7, 1847, 2. 
to monkeyism" as well as a "slim and spare" physique, lacking the vitality "noticeable among our own people." Due to alleged cultural and bodily frailty, they were called "this last greatest work of God." ${ }^{22}$ Chinese, therefore, were just like immature children in front of Americans, who deemed themselves fully developed adults.

While examining Chinese bodily and mental features, spectators also tried to have a peep at Chinese life details. From their observations and peeks, Americans garnered whatever information that could be useful in proving Chinese lowliness on the civilization ladder.

From Hesing, Americans reinforced their impression that Chinese gender norm was the inverse of the American one. Shortly after the Keying arrived in New York, some residents went aboard and "enjoyed a few minutes' conversation with Hesing, a Mandarin of the Red Button." The consequent report displayed American disdain at Chinese polygamy by quoting Hesing in his pidgin English. Hesing admitted having three wives. As to why he did not take more, he explained, "No can cathee more, costee too muchee dollar." What if his wives quarreled? This Chinese "replied with perfect gravity, "horse whippee." Hesing also disclosed that the Chinese artist was "the happy proprietor of two wives." Evidently proud of Chinese marriage institution, Hesing "politely expressed a feeling which was not admiration" at American monogamy. ${ }^{23}$

Another American called Hesing "the happy husband of only [italics added] three spouses" and deemed "barbarous" his opinion that women must remain indoors and reticent unless spoken to by "their lawful lords." This person also quoted Hesing's pidgin English to highlight the hilarious effect of his talk. Hesing found American women "too muchee plenty" and "too much talkee, talkee!" on the streets. American females" "too small fat, too muchee foot" disturbed him too. He pointed to a passing lady as his "ideal of personal beauty," but that woman "weighed, as we should judge, not much more than two hundred [pounds]!"24 The Ypsilanti Sentinel, though published in distant Michigan, showed the same interest in and contempt at Hesing's position on females. It jeered that "Broadway gals" did not conform to his standard of beauty, since "no hab little footee, and

22 "Traits of the Chinese," Republican Farmer, Oct. 12, 1847, 1.

23 "The Chinese Junk," Pennsylvania Freeman, Jul. 15, 1847, 3.

24 "Hesing, the Mandarin of the Chinese Junk," American \& Commercial Daily Advertiser, Jul. 28, 1847, 2; "Chinese Notions of American Ladies," Wilmington Journal, Aug. 13, 1847, 1. 
muchee fat." 25 In a similarly sarcastic tone, the Scientific American wrote, "[T]he absence of small feet in our females, have given them [the Chinese on the Keying] an exceedingly poor idea of our taste for female beauty, and they consider that our affection cannot be much for 'dear woman' when it is bounded by a single wife." 26

Even when not seeing or hearing anything that could prove their suppositions, Americans could still draw evidences simply from their imaginations. Take for example the supposedly savage culinary habits of the Chinese. Americans admitted not finding anything on the junk that could infer Chinese eating of vermin like rats, but they believed that the Chinese did and thus did everything to publicize this counterfactual belief. On the same visit when Hesing confessed having three wives, the New York Tribune reporter took "a little Chow chow (chaw-chaw dinner)" at the captain's invitation. Chaw-chaw should be Chaozhou in modern Chinese pinyin, which is a prefecture in the Chinese province of Guangdong. But he did not think the meal authentically Chinese, because there was not "a single rat or joint of a young puppy being on the table." 27 A July 28, 1847, article in the New York Herald described "a great day in their [Chinese] religious calendar," when the sailors would make offerings to their gods. It claimed that "Any quantity of corned beef, rats, dogs, cats, and other luxuries have been made," naming whatever vermin that Americans believed Chinese should eat without explaining how the sailors could obtain those "luxuries" in the first place. ${ }^{28}$ Another baseless accusation appeared in Indiana's Richmond Palladium, which asserted on September 7 that "The Chinese on board the Junk at New York, it is stated, eat rats, cats and mice with an astonishing relish." ${ }^{29}$

Some people even prodded local government to entertain the Chinese with dishes of rats and cats. On July 12, 1847, the New York Board of Aldermen decided to appoint a special committee to tender the officers of the Keying and a French steamer with "the usual hospitalities of the City." ${ }^{30}$ The reception was held that night. Pretending to demand justice for "the

25 "The Long Expected Chinese Junk," Ypsilanti Sentinel, Jul. 21, 1847, 2.

26 "Home Compendium," Scientific American, Jul. 17, 1847, 338.

27 "More about the 'Junk,"” Boston Weekly Messenger, Jul. 14, 1847, 2; "The Chinese Junk," Pennsylvania Freeman, Jul. 15, 1847, 3.

28 "The Chinese Junk," New York Herald, Jul. 28, 1847, 2.

29 "The Chinese," Richmond Palladium, Sept. 7, 1847, 3.

30 Proceedings and Documents of the Board of Assistant Aldermen, from May $11^{\text {th }}$ to November 25 $5^{\text {th }}, 1847$, vol. XXX (New York: Thomas Snowden, 1847), 178; “The Chinese Junk,” New York Herald, Jul. 13, 1847, 2. 
bewildered, long tailed little men," the New York Commercial Advertiser suggested that the city government hold a banquet for them. It would cost little, since New Yorkers could easily supply a large number of dogs and the "necessary quantities of 'small deer'--rats and kittens" by placing one or two dozen traps in markets. ${ }^{31}$ In the last days of August, when the junk was expected to leave, the Advertiser once again urged the city council to offer "a grand entertainment...on board the Keying, cats and dogs to form the repast" as an "acknowledgment of the pleasure" that the Chinese had brought to local people..$^{32}$

At the same time, it is imperative to note that not all American depictions were negative. For example, some reports stressed Chinese ingenuity in making the Keying seaworthy, suggesting that "our shipwrights had better examine the manner of her make, \&c. as they may, though termed by the Celestials, as outside 'barbarians,' gather some hints that may prove useful" while another comment encouraged American cabinet makers to copy "many pieces of beautiful Chinese furniture" on the junk. ${ }^{33}$ Other people admitted being wrong in assuming Chinese to be barbarous. A letter to Washington, D.C.'s Weekly National Intelligencer wrote that the British captain considered his Chinese crew "savage and barbarous," but "The Chinese, however, do not look very savage now." ${ }^{4}$ The Daily National Intelligencer in the same city, on the other hand, found out that the Keying cordage was "laid up with a regularity that shows the Chinese to be far from ignorant, and proves that they have arrived as near perfection as we have in the article of cordage, though their material is rough and their machinery nothing." ${ }^{35}$ Even the always critical New York Herald had to concede "a great mistake" in speaking of Chinese as "a barbarous and unenlightened people," since on the junk were "specimens of portrait painting which are highly creditable to their artists." 36

However, these compliments were outnumbered by scornful depictions. What began as a voyeuristic experience had turned into a social ritual by

31 "By the Pilot Line," Pennsylvania Inquirer and National Gazette, Jul. 14, 1847, 3; "The Chinese Junk," New-York Commercial Advertiser, Jul. 29, 1847, 2.

32 “Entertainment Proposed," New-York Commercial Advertiser, Aug. 23, 1847, 2.

33 “The Chinese Junk," Southern Patriot, Jul. 15, 1847, 2; “The Chinese Junk 'Keying," Pittsfield Sun, Jul. 22, 1847, 1; "A Chinese Vessel," Maine Cultivator and Hallowell Gazette, Jul. 17, 1847, 2.

34 "New York Correspondence," Weekly National Intelligencer, Jul. 17, 1847, 4.

35 "What the Chinese Junk Looks Like," Daily National Intelligencer, Jul. 28, 1847, 2.

36 "The Chinese Junk," New York Herald, Jul. 23, 1847. 
which American society learned, constructed, and reinforced the notion of Chinese childishness and inferiority. This is part of the first edge of the triangle that governed American racialization of the Keying Chinese.

\section{American Paternalism}

Another component of the first edge is American paternalism. Racial disdain aside, Americans also considered those sailors worthy of their care and protection. Though this paternalistic sentiment reflects an intention to treat Chinese as an effete other, it actually represents the humane side of American racialization of Chinese in the 1840s. The dispute between the Chinese sailors and their British captain over unpaid wages supplies an entry point to the functions of American paternalism.

According to court records, the Chinese sailors were deceived into traveling to the United States. They did not receive the promised pay and were maltreated when they rebelled. At the first news of Chinese sufferings, Americans had manifested their sympathy and willingness to help, though sometimes with restraint. The New-York Mail was the first paper to disclose that the British captain had coerced the Chinese crew into coming to America and that he was keeping their wages. On July 24, the Morning News of Connecticut reprinted one of its articles, offering "a direct statement of very flagrant acts" by the British against "these poor creatures" on the junk. The acts included not only deception but "gross violence and cruelty," even death of a sailor. The Mail desired a thorough investigation into the whole issue. Though the Morning News suspected it to be one of "celestial falsehoods," it still assumed that the rumor "should and we dare say will be looked into, nevertheless." 37 Two days later, the Boston Daily Evening Transcript reported the same story. It said that the Chinese had been taken to "this remote part of the world by violence done to their inclinations and national habits." While professing "no desire to originate or circulate injurious rumors" and warning of a possible "'bounce' of John Chinaman," the newspaper did call for "further inquiry...at all events." 38

Warm-hearted Americans also acted. On August 13 and 19, 1847, in an article taken from the Albany Evening Journal, the Boston Daily Bee and the Boston Recorder reiterated the captain's "ill-usage" of the Chinese sail- 
ors and mentioned a specific "American gentleman" who turned out to be righteous. The gentleman was said to have resided in the sailors' home prefecture for five years and could speak their dialect. When he boarded the junk for a visit "a week or ten days" after its arrival in New York, that is, in late July, the Chinese related to him their sufferings. Appalled by what had happened on board the Keying, he pulled together with several local merchants to demand the captain to pay overdue wages and provide for the sailors' return to China in an American ship. The Englishman first resisted but later agreed to make arrangements "for the return of the men who were inveigled from their homes." 39

Lin King Chew (Lin Jingzhou or Lin Zhen in modern pinyin), a Chinese merchant who happened to be in New York in 1847-1848, also recorded this chance encounter in his Chinese-language memoir: "In June 1847, as soon as I arrived in the Flowery Flag Country, I found the junk anchored in the harbor for examination. Several days later I and a companion disembarked [my vessel] to inquire what had happened. That was when I got to know that the Englishman had cheated them." ${ }^{40}$ Lin was talking about the lunar calendar, so June should be July, which was exactly when the Keying reached New York. His companion must be that American gentleman, whose identity cannot be established for the lack of relevant sources.

This American effort was obviously not forceful enough to ensure the English captain's compliance. So the dispute continued fermenting until it erupted into a physical conflict between the Chinese and the English on August 30 . Both parties suffered injuries, with seven Chinese arrested by local police. Concerning the reason for the brawl, there arose accusations of Chinese responsibility. In one narration, the sailors wanted to have their wages back but declined to hand over their contract. When the British refused their request, the Chinese assaulted with "the most horrible howlings" but without any "heretofore recognized system of tactics." The British eventually "had the best of it" and the most belligerent Chinese were taken into custody. ${ }^{41}$ Even a newspaper in distant Louisiana belatedly noticed this "Chinese row," believing it originated in a Chinese plot "to violate their contract with Capt. Kellet." 42

39 “The Chinese Junk," Boston Daily Bee, Aug. 13, 1847, 1; Boston Recorder, Aug. 19, 1847, 3.

40 Lin Zhen, Jiuhui Beiyou Chaoren Ji (An Account of Saving Deceived Chaozhou People), in Zhong Shuhe, comp., Zouxiang Shijie Congshu (From East to West: Chinese Travelers before 1911), vol. 1 (Changsha: Yuelu Shushe, 2008), 45.

41 "The Chinese Junk," Berkshire County Whig, Sept. 16, 1847, 2.

42 “A Chinese Row," Democratic Advocate, Sept. 22, 1847, 2. 
Some media went so far as to accuse those Chinese of attacking under opium-incited hallucination. One article told readers that the sailors, after taking "a little too much opium in their pipes" and becoming "to some extent intoxicated," declined to sign the wage receipt. The captain withdrew the money, and they fell down "in a sort of Chinese hysterics, and otherwise...make a disturbance on the premises." ${ }^{43}$ The Connecticut Constitution, besides blaming the sailors for attacking the Englishmen "under the excitement of the opium," vowed that somebody had actually seen "two of them evince a similar spirit some time ago," making the slander much more deceptive. ${ }^{44}$

But fortunately, such groundless finger-pointing did not last long. On September 3, with the help of righteous Americans, those seven Chinese finally had the chance to prove their innocence and obtain justice at court. In subsequent developments, Americans helped the Chinese win the lawsuit and compelled the captain to capitulate. This indeed demonstrated American impartiality and benevolence, which Americans did not hesitate to give enormous publicity.

In a special court in New York, with attorney Daniel Lord's and other Americans' help, the captain's dishonesty and maltreatment of his Chinese crew were laid bare. As reported by the Albany Journal and other newspapers, the judge acquitted and released the sailors, who were "evidently much pleased with American justice" when leaving the court. Among those other Americans who offered a helping hand was S. Wells Williams. Williams had been a missionary in China since 1833 and was then on vacation in America. It was through his interpretation that the original contract between Kellett and the Chinese became known to the court and the public, clearing the sailors of any wrongdoing. The Journal also predicted that the Chinese would leave America for China in a few days "under the auspices of several benevolent individuals, who have taken a deep interest in their behalf." 45

In Lin King Chew's memoir there is also a narrative of the trial emphasizing American benevolence. Of course he claimed doing the translation

43 "Difficulties at the Chinese Junk," Daily National Intelligencer, Sept. 4, 1847, 3.

44 "A Chinese Junketing," Constitution, Sept. 8, 1847, 2.

45 "The Celestials in Court," Albany Journal, Sept. 6, 1847, 2; Boston Weekly Messenger, Sept. 8, 1847, 3; Barre Patriot, Sept. 24, 1847, 2; "Some Difficulty," American \& Commercial Daily Advertiser, Sept. 6, 1847,6 . 
himself: "At the time I was sitting in on the trial. So I went forward and translated the entire matter. Picking one of the 19 Chinese in the room as witness, I translated their contract on the spot." But this did not downscale his praise for American friendliness towards the Chinese. He specifically underlined the American lawyer's wholehearted defense of the accused. He wrote, "Mr. Lord sat on the right, refuting the British methodically while the British trembled with fear and sweat." When the judge announced the acquittal of the Chinese, the mostly American audience showed their extreme satisfaction with "a thunderous applause." 46

While the Chinese were waiting for the verdict to take effect, Americans continued to treat them with care and patronage. In the libel against the junk to the judge of New York Southern District, Attorney Lord and U.S. Commissioner Charles W. Morton again depicted Chinese sufferings in a rather compassionate manner. The document pointed out that the sailors "were forced by violence and severity, by blows and stripes, to work the junk on her voyage" and were "destitute of all means of support, and of all means of getting home to China, and ...unprovided with clothing or necessaries for resisting the weather of the cold climate of this country." Over the opposition of Capt. Kellet's attorney, the judge allowed the libel order, showing his recognition of and sympathy to Chinese miseries. ${ }^{47}$ American benevolence and justice finally triumphed when, after a series of follow-up measures by the court and the lawyer, Kellett paid $\$ 1,000$ ( $\$ 20,000$ in today's money) for Chinese sailors' return to Canton, "amicably" settling the dispute. ${ }^{48}$ As to whether the Chinese had got back their wages, the answer, though not explicitly mentioned by the press, should be affirmative, given the priority of that demand in the entire legal process.

In the wake of the lawsuit, American newspapers continued expressing their concern in various ways. On September 6, while summarizing the entire case, the American \& Commercial Daily Advertiser of Baltimore called the sailors "these unfortunates" and announced that "some gentlemen...

46 Lin, Jiuhui Beiyou Chaoren Ji, 46-47.

47 "Libel in Rem by the Seamen of a Chinese Junk for Wages, Expenses, and Passage Money Home," in Erastus C. Benedict, The American Admiralty: Its Jurisdiction and Practice with Practical Forms and Directions (New York: Banks, Gould \& Co., 1850), 497; “The Chinese Junk," Newark Daily Advertiser, Sept. 8, 1847, 2 .

48 “The Chinese Junk," New-York Spectator, Sept. 11, 1847, 1; "United States of America," New-York Commercial Advertiser, Sept. 23, 1847, 4; “The Chinese Junk,” Daily Evening Transcript, Oct. 4, 1847, 2 
are determined that justice shall be done" to them. ${ }^{49}$ On September 17, the Schenectady Reflector of New York reprinted a brief comment from the New York Express. The piece, though blaming the lawyer's libel against the junk for making the sailors "supperless and dinnerless," showed considerable sympathy to the Chinese who were "wandering about our city homeless and houseless." 50

Fortunately, one American came forward and took them to a refuge called Sailor's Home. It was there that the Chinese experienced another round of American paternalism. American documents did not contain much information about their stay in that place. But Lin kept a record in his memoir. Identifying the helpful person as his friend Mr. Richardson, he recollected,

The following day I and Lord became famous far and near. We arranged for all the sailors concerned to move their luggage into Richardson's home [Sailor's Home]. As the head of sailors of all nationalities, Richardson was brave and upright, treating all of us as brothers and asking no monthly rent for our stay. ${ }^{51}$

Though American newspapers said almost nothing about the care that the Chinese received at the Home, they did reveal Chinese thankfulness to their American friends at the end of their sojourn, proving the presence of American paternalism indirectly. On October 4, twenty six Chinese embarked on their journey home in the American bark Candace. "An Episcopalian" left a detailed description of how the sailors bid their emotional goodbye and shed their tears of thanks to Americans. Captain and Mrs. Richardson's assistance was explicitly termed "paternal and maternal care," which deserved and was actually rewarded with "the strongest terms of gratitude" on the part of the sailors. The Chinese "felt so much love" toward their compatriot Lin, "a devoted Christian," for tending "their spiritual welfare" that they begged the Richardsons to take care of him with the same "sympathy and kindness they had so recently experienced." In order to forever remember their feelings at departure, they decided to transplant one "American "cry tree" - willow - back to China. As the ship sped towards the open sea, "her bulwarks were lined with the 26 Chinese sailors, in tears at parting with their kind friends." The sailors flourished their caps and gave three

49 “Some Difficulty," American \& Commercial Daily Advertiser, Sept. 6, 1847, 6.

50 "The Chinese Junk," Schenectady Reflector, Sept. 17, 1847, 2.

51 Lin, Jiuhui Beiyou Chaoren Ji, 46; "Interesting Services," New-York Spectator, Oct. 13, 1847, 4. 
cheers, which were answered by American ladies and gentlemen. At the end of all these, the Chinese started a farewell song "in their harsh, cracked voices." Deeply moved by those sincere sentiments, the "Episcopalian" believed that "the scene was truly worthy of an artist's pencil." 52

Other records also noted and publicized the paternalistic concern that those Chinese had received and thanked. An article carried by the New-York Spectator on October 13, 1847 deemed it "affecting to see the tear falling from the cheek of some of these celestials as they were shaking hands and bidding good-bye to some of us "barbarians." That the Chinese were so much touched by American paternalism was hailed as a proof that "commerce and Christian charity and goodness are breaking down the wall of partition between China and other countries, and conquering them more effectually far than war." ${ }^{33}$ The following day, the Boston Recorder echoed this judgment by stating that the Chinese had only "escaped still worse usage through the intervention and kind protection of the law." Lin, "an educated Christian man," received his share of praise for instructing the unfortunate Chinese spiritually at the Sailor's Home..$^{54}$

But for his part in this legal case, Lin King Chew was revenged by the British captain and his associates. His final exemption from prosecution was another, though a minor, case of American care and righteousness. As Lin himself recalled,

Because I prevented the Englishman from carrying out his wicked plot and he knew I was learning photography, he told his photographer friend to claim that what I had purchased was actually stolen from him....On the night of the twenty-ninth police came to arrest me. The following morning, I breakfasted with the police officer at the Richardsons. Richardson's daughter begged his father and brother to assist me to the best of their ability. By noon, knowing the details of the affair, the local authorities allowed her father to bail me out with a surety of $\$ 300$. Thereafter...Mr. Lord presented the police with the merits of the case on my behalf and proved my innocence..$^{55}$

Obviously, due to the "sympathy and kindness" that friendly Americans offered, Lin succeeded in thwarting Kellet's attempt to frame him. The larger

52 An Episcopalian, "Sailing of the Chinese Sailors, Belonging to the Cochin China Junk," Salem Register, Oct. 11, 1847, 2 .

53 “Interesting Services," New-York Spectator, Oct. 13, 1847, 4.

54 "Chinamen," Boston Recorder, Oct. 14, 1847, 3.

55 Lin, Jiuhui Beiyou Chaoren Ji, 46-47. 
society, however, did not pay much attention to this charge of theft, possibly because it was not so dramatic as the dispute between the Chinese crew and their British captain. One of the few reports, without knowing that Lin had proved his innocence immediately, lamented that "when he arrived in New-York, he was as innocent as a babe unborn! But he is beginning to be civilized." ${ }^{56}$ Regardless of its jocular tone, this comment metaphorically defined Americans themselves as sophisticated adults whereas the Chinese were only green and naive babies. Such a comparison can be read as another sign of American paternalism and superiority mentality in the face of the Chinese.

The Candace carried away 26 Chinese, leaving Hesing and around 15 others to voluntarily continue the journey to Boston and eventually to England. Nobody knows for sure Hesing's final fate, despite rumors that he stayed at a grocery and tea store in London. The other crew members either remained in Britain or returned to Canton..$^{57}$ As to Lin, he lingered in America, visiting many other places besides New York. He eventually returned to China in March 1849. ${ }^{58}$

\section{Chinese vis-a-vis America's Other Non-Whites}

Thus far, one could see that contemporaneous Americans harbored a mixed sentiment toward the Keying Chinese. They regarded the sailors as inferior, exotic strangers but displayed sufficient paternalism to keep them out of harm's way. Chinese composed a backward but pitiful group in front of progressive and righteous Americans. This definition situated Chinese only vis-a-vis American whites themselves. But when the Keying arrived, the United States already had several other non-white groups, mainly blacks, Indians, and Mexicans, the latter defeated in the Mexican War and incorporated in large numbers. To precisely categorize Chinese as a racial group, American whites had to and did refer to these three groups. Their intention in doing so and consequent comparisons and contrasts formed the other two edges of the triangle that this essay has been trying to reconstruct.

African Americans were undoubtedly the largest group of non-whites when the Keying arrived. So American whites spontaneously thought of blacks when trying to project the Chinese on America's racial map. Blacks

56 “Man," Daily Sentinel and Gazette, Nov. 4, 1847, 2.

57 “Chinese Junk, or Celestial Ship," Boston Daily Bee, Dec. 6, 1847, 1; Davis, East Sails West, 137, 185-88. 58 Lin, Jiuhui Beiyou Chaoren Ji, 47. 
were fixed to the lowest rung of the racial hierarchy, but how far upward were the Chinese, if at all?

For one thing, Americans deemed the Chinese so similar to blacks in appearance and plight that they could be easily confused. For instance, when many people doubted the genuineness of the Chinese junk, it was because of the supposed indistinguishableness between Chinese and blacks. As an article that originated in the Brooklyn Eagle professed, the vessel was built near Philadelphia under the superintendence of a New Yorker. The crew on the boat were mixed, believed to be "one third American whites and two thirds negroes or mulattoes." 59 In the author's mind, American whites were passing for European sailors on the boat whereas "negroes or mulattoes" were performing the role of Chinese. That American and European whites could be mistaken for each other was not surprising, but his taking Chinese as blacks speaks much about some Americans' readiness to lump the two groups together without much differentiation. A piece of Newark Daily Advertiser correspondence criticized these doubts of the Chinese origin of the junk but also revealed many Americans' subconscious inclination to associate Chinese with blacks. It said that those "fault-finding" people suspected the junk to be a fake partially because they considered the Chinese sailors as "relatives of Joice Heth and the musical Ethiopians." 60 "A black, old, toothless, blind, crippled slave woman," Joice Heth was on exhibit in 1835 as George Washington's 161-year-old nurse-maid, which was of course a hoax. ${ }^{61}$ As the kin of Heth and Ethiopians, the Chinese naturally fell into the category of blacks.

Not only did Americans hold Chinese close to blacks, they sometimes even treated the sailors the same way that they did blacks. For example, according to the Mississippi Creole of October 16, 1847, "a party of native and meddlesome abolitionists" boarded the Keying as soon as it arrived, censuring the captain for "holding so many of his colored brethren in bondage" and threatening him with possible writs of habeas corpus for the entire Chinese crew. But when induced to escape to Canada, the Chinese showed their unwillingness with an attempted assault on the abolition-

59 "The 'Chinese Junk,"” Newport Mercury, Jul. 24, 1847, 2.

60 “Luxury," Newark Daily Advertiser, Nov. 20, 1847, 2.

61 Rosemarie Garland Thomson, Extraordinary Bodies: Figuring Physical Disability in American Culture and Literature (New York: Columbia University Press, 1997), 59. 
ists. The newspaper contended that those Americans actually knew nothing about the Chinese except their "pretty dark yellow" skin color. That the Chinese were colored "was enough for them." The article ridiculed that these abolitionists' sympathies were "in proportion to the color of the objects" and "a starving white man excites their benevolence much less than a lusty well fed negro." 62 Thus white abolitionists' compassion to the Chinese originated in their belief that blacks and Chinese were identical. A report in the Wisconsin Democrat echoed this perception. Holding certain "roguish speculators" responsible for troubles befalling the Chinese sailors after their conflict with the British captain, it blamed those Americans for first temping the Chinese to leave the junk and then allowing them to "shift for themselves, or starve!" The author likened the Chinese situation to that of blacks at the hands of abolitionists: "How very like this is our Northern philanthropy for the Southern slaves." 63

Meanwhile, some Americans did attempt to treat Chinese as a group more tolerable than blacks. The Keying Chinese worked under the sun all day long. Many people actually noticed that this made them appear "dark," which is possibly the reason that they deemed Chinese and blacks closely affiliated. Yet, many others were perceptive enough to notice their difference and treat them differently. On July 17, 1847, a letter carried by the Newark Daily Advertiser conceded that the skins of the Chinese sailors were "scarcely a shade lighter than the African's." But immediately the correspondent added his belief that the Chinese skin color was "the result... of much exposure." ${ }^{\prime 4}$ This meant that Chinese were racially not as dark as African Americans, which carried weight in a period when people tended to determine race by skin tone.

Motivated by this line of reasoning and also driven by curiosity, huge numbers of American whites were willing to be closer to the Chinese sailors than to blacks, incurring the reproach by abolitionist-minded people. According to the Anti-Slavery Bugle of New-Lisbon, Ohio, the black editor of the Ram's Horn once tried to visit the Chinese junk but was denied entry because he was colored. The Bugle suspected that such a decision

62 "The Chinese Junk and the Emancipators," Mississippi Creole, Oct. 16, 1847, 1.

63 "Happy Firm!" Wisconsin Democrat, Sept. 25, 1847, 2.

64 "Correspondence of the Newark Daily Advertiser, New York, July 16, 1847," Newark Daily Advertiser, Jul. 17, 1847, 2 . 
was made "in deference to the taste of the sovereigns of New York, and probably...not...without the advice of some of them." This "remarkable" event enraged pro-abolition people not because of whites' conspiracy but because of whites' tolerant treatment of the Chinese. American white "ladies and gentlemen" were said to have crowded "in the closest proximity with these sweltering, black, and dirty Chinamen," with "no prejudice here against colored men." The paper declared that it "quite passes our comprehension" to see these same whites "turn up their noses at respectable colored Americans, and not permit them to stand within the same hundred feet of out-o'-doors as themselves." Despite the Bugle's opposition to white visitors' different treatment of Chinese and blacks, it cautiously qualified its disdain at the sailors to imply that Chinese overall may not be so despicable. The article emphasized that those on the junk were "of the lowest class of Chinamen, called coolies," who had "no very high reputation in their own country for cleanliness." 65 Though stopping short of comparing the entire Chinese race to blacks, these words surely lead one to think that even those who considered Chinese no better than blacks may have harbored a relatively benign idea of the Chinese as a racial group. This was the case with many contemporaneous abolitionist reports, which explicitly announced that Chinese were as laborious and robust as "the best Africans" and "more intelligent." 66

Obviously, to many Americans, Chinese, especially of the lowest class, were similar to blacks in skin color and pitifulness but represented a more tolerable racial presence. However, when situating Chinese alongside Mexicans, another racial group that was catching American attention because of the U.S. expansion into Mexican territory in the 1840s, Americans gave an apparently lower appraisal of Chinese. Almaguer and O'Brien contend that since European colonization had conferred on Mexicans a "white" and "half-civilized" status, Americans have considered persons of Mexican origin more worthy of acceptance and assimilation than other colored races, granting them more privileges accordingly. ${ }^{67}$

This American practice of positioning Mexicans higher than other disadvantaged groups was actually present in at least one comment on the Key-

65 "Colorphobia," Anti-Slavery Bugle, Aug. 27, 1847, 2.

66 Lucy M. Cohen, Chinese in the Post-Civil War South: A People without a History (Baton Rouge: Louisiana State University Press, 1984), 52.

67 Almaguer, Racial Fault Lines, 4; O’Brien, Racial Divide, 3. 
ing. Since the junk, "bored for carrying 30 guns," possessed "the combined qualities of a Trader and a vessel of War" and even certain primitive fighting capability, Americans believed that it could furnish "a sufficiently accurate index to the military appointments of the celestial empire." ${ }^{68}$ Holding such an assumption, on July 30, 1847, the Morning News carried an analysis of Chinese military capability to show that American victory against Mexicans was not so easy as the British press alleged. Anyhow, Mexicans were more advanced than Chinese. It mocked that the ordinance of the Keying was "about upon a par with the make-believe artillery of a boy regiment in celebrating the $4^{\text {th }}$ of July," providing Chinese soldiers with only "a thin bamboo matting" protection against enemy guns. In sharp contrast, the Mexicans that Americans had been battling were "veteran troops well supplied with the means of defence and fighting with great gallantry." Therefore, as the News announced, Britain should not call Americans cowards for their defeat of Mexico while reveling in their own heroics against the "paper shielded creatures" of China ${ }^{69}$ While what the Morning News intended to do here was to glorify American valiance, it did unveil Americans' desire to position Mexicans higher than the Chinese on the racial hierarchy.

The third racial minority to whom American press compared Chinese was American Indians. But the comparison only went so far as to emphasize the resemblance between Chinese and Indian appearances, without apparent suggestion at their degrees of cultural and racial advancement. One similarity concerned their physical features. On August 26, 1847, the Jeffersonian Republican of Stroudsburg, Pennsylvania announced that the Chinese on board the Keying "very closely resemble the aborigines of this country." It then listed their common characteristics, including "tawny complexions, high cheek bones, and long black hair." The author professed himself to be a doctor, adding a scientific and professional luster to his discovery of Chinese-Indian likeness. ${ }^{70}$ On September 7, the Richmond Palladium of Indiana also noticed the bodily alikeness between the two groups. A brief report likened the skin color of the Chinese on the junk to that of Indians: "They are dark-colored, and resemble our North American Indians.""11

68 The Chinese Junk “Keying,” Being a Full Account of That Vessel, with Extracts from the Journal of Capt. Kellet (New York: Printed for Israel Sackett, 1847), 4; “The Chinese Junk," Pennsylvania Freeman, Jul. 15, 1847, 3; "The Chinese Junk," Scientific American, Jul. 24, 1847, 347.

69 “The Chinese Junk," Morning News, Jul. 30, 1847, 2; People's Advocate, and New-London County Republican, Aug. 4, 1847, 2.

70 "Pencillings at Random," Jeffersonian Republican (PA), Aug. 26, 1847, 2.

71 "The Chinese on Board the Junk," Richmond Palladium, Sept. 7, 1847, 3. 
In the few press descriptions, not only did Chinese and Indians share certain physical features, their attires were equally amusing to Americans. On July 16, 1847, the State Gazette of Trenton, New Jersey published a letter from New York. The author revealed that the Chinese on the Keying "have not a particle of apparel on them but a breech cloth, similar to that worn by our Indians." This sartorial style looked, of course, strange to Americans, who suggested that they "remain pent up in their vessel during the time they remain there." But at the same time, Americans would not like the Chinese to don American-style "broadcloth and tight jackets," for that would compose "a curious spectacle" too. ${ }^{72}$ Thus neither Chinese nor Indians could hope to look American even by adopting American dressing style; they were and would remain strangers in the United States. A September 6 report highlighted the supposed hilarity of both Chinese and Indian attires by showcasing their curiosity at each other. It said that on the fourth of that month, three or four Indians from north of New York visited the Keying. White spectators found it "very amusing" to witness Indian curiosity at "the long ques of the Chinese and their chin-chining [worshiping ritual]" and the curiosity "fully reciprocated by the Celestials, who were equally amazed at the dress and language of the Indians." ${ }^{73}$ By turning Chinese-Indian mutual interest into a spectacle, American press had theatricalized both groups and fixed them to the same level of racial queerness.

In the 1840s, Americans obviously knew blacks, Mexicans, and Indians much better than they knew Chinese. That is why they employed the three groups as coordinates to determine the position of Chinese on America's racial map. Chinese were defined as a group that resembled Indians in appearance, seemed a bit more tolerable than blacks, but noticeably less developed than Mexicans. In a nutshell, based on these comparisons and contrasts, Americans had assigned Chinese a niche on their racial ladder slightly higher than the bottom.

72 “The Chinese Junk," State Gazette, Jul. 16, 1847, 2.

73 "By the Pilot Line," Pennsylvania Inquirer and National Gazette, Sept. 6, 1847, 3. 


\section{Conclusion}

So the Chinese junk had helped bring into focus America's triangular paradigm for the racialization of Chinese. In this triangle, American whites occupied the top corner, commanding the discursive weapon of mass publications to position Chinese relative to whites themselves and other non-whites. Thus triangulated, the Chinese, as represented by the sailors, appeared inferior to and weaker than whites, much alike Indians in appearance, but stood somewhere in between blacks and Mexicans. This positioning treated Chinese as a purely sojourning group, showing no signs that Americans had considered the possibility of their becoming civil or political participants in the society someday. It is therefore the prototypical paradigm that American whites used to racialize Chinese and an overture to future racializing strategies exemplified by Kim's pattern. Whites may have employed similar designs to accommodate other racial groups in their first days in America, but that needs additional papers to deal with and lies beyond what the current essay could do.

The significance of the Keying-effected paradigm did not end with the departure of the junk for Britain in February 1848. Instead, it was gradually revived one year later, when Chinese immigrants began to flood into the United States. Of course, over time the scheme would undergo modifications. For instance, Americans' curiosity at Chinese would decrease. When Chinese immigrants began to compose a "threat" to both American jobs and culture in the latter half of the nineteenth century, American paternalism would also take a noticeable downturn. So in due time Americans' voyeuristic disparagement plus paternalism on the first edge of the triangle would be partially replaced with animosity (or ostracism, as Kim terms it) toward Chinese. However, the second edge would remain with only slight changes. White Americans would keep on comparing Chinese to similarly racialized groups, which would include not only blacks, Indians, and Mexicans, but other groups like Irishmen as well. As to the bottom edge, the situation might be more complicated, since whites' actual positioning of Chinese relative to themselves and other minorities would vary radically against different backgrounds.

With Chinese and other minorities assuming more agency later on, it would result in more active responses from the racialized; for instance, Asian Americans would deliberately orientalize themselves to expose the absurdity of white racism or gain benefits from whites; there would also be more rivalry between racial groups for civil and political privileges. Chi- 
nese-black competition is one example of the latter situation. ${ }^{74}$ Whites, in turn, would diversify their approaches to racial minorities accordingly. One result of this diversification is whites' valorization of Asian cultural and racial traits in the face of African Americans, which Kim has highlighted in her triangle. In this sense, the triangular pattern that the Keying occasioned is a hitherto largely unnoticed prelude to the more complicated modern configuration of race and an echo to the "go beyond the white-black binary" call by students of American racial history.

74 Sylvia Shin Huey Chong, "Orientalism," in Cathy J. Schlund-Vials, Linda Trinh Vo, and K. Scott Wong, eds., Keywords for Asian American Studies (New York: New York University Press, 2015), 182-184; Helen Heran Jun, Race for Citizenship: Black Orientalism and Asian Uplift from Pre-Emancipation to Neoliberal America (New York: New York University Press, 2011), 3-31; Edlie L. Wong, Racial Reconstruction: Black Inclusion, Chinese Exclusion, and the Fictions of Citizenship (New York: New York University Press, 2015), 21-24; Sherrow O. Pinder, Whiteness and Racialized Ethnic Groups in the United States: The Politics of Remembering (Lanham, MD: Lexington Books, 2012), 47. 